\title{
Model Pembelajaran Snowball Throwing Berbantuan Media Audio Visual Terhadap Kompetensi Pengetahuan IPA
}

\author{
Shinta Pradnya Dewi*, I Ketut Ardana², I Gusti Ayu Agung Sri Asri³ \\ 123 Program Studi Pendidikan Guru Sekolah Dasar Universitas Pendidikan Ganesha
}

\begin{abstract}
Abstrak
Penelitian ini bertujuan untuk mengkaji pengaruh model pembelajaran snowball throwing berbantuan media audio visual terhadap kompetensi pengetahuan IPA kelas V SD Negeri Gugus RA Kartini tahun ajaran 2019/2020. Penelitian ini merupakan jenis penelitian eksperimen semu dengan nonequivalent control group design terhadap 36 siswa kelas VA SD Negeri 19 Pemecutan sebagai kelas eksperimen dan 33 siswa kelas V SD Negeri 15 Pemecutan sebagai kelas kontrol yang diambil dengan teknik simple random sampling. Data dikumpulkan dengan 30 soal Pilihan Ganda Biasa yang telah diuji validitas dan reliabilitasnya. Pembelajaran pada kelas eksperimen melalui model snowball throwing berbantuan media audio visual dan pada kelas kontrol diberikan pembelajaran konvensional. Perlakuan pada kelas eksperimen dan kontrol diberikan sebanyak 6 kali. Rata - rata nilai pada kelompok eskperimen setelah diberikan perlakuan yakni $74,04 \pm 10,30$ dan rata - rata kelompok kontrol 54,78 $\pm 11,96$. Kedua data dinyatakan berdistribusi normal dan homogen, selanjutnya dilakukan pengujian hipotesis dengan uji-t yang memperoleh hasil thitung $=6,867$ tabel $=2,000$ dalam taraf signifikansi $5 \%$ dengan $\mathrm{dk}=33+30-2=61$. Berdasarkan perhitungan uji $\mathrm{t}$ tersebut maka dapat ditarik simpulan model pembelajaran snowball throwing berbantuan media audio visual berpengaruh terhadap kompetensi pengetahuan IPA siswa. Penelitian ini membuktikan bahwa model snowball throwing berbantuan media audio visual baik diterapkan dalam proses pembelajaran sebagai upaya meningkatkan pengetahuan siswa pada muatan materi IPA
\end{abstract}

\begin{abstract}
This research aims to determine the effect of a snowball throwing learning model assisted by audio-visual media to the science competency of class V elementary School, RA Kartini, school year 2019/2020. This research is a kind of research pseudo-experimentation with nonequivalent control group design towards 36 class VA students SD Negeri 19 Pemecutan as class of experimentation and 33 grade V students elementary School 15 Pemecutan as a control class taken with simple random sampling technique. The data is collected with 30 questions regular double choice has been tested for its validity and reliability. Learning in experimentation classes through the snowball throwing model assisted by audio visual media and control groups were given conventional learning. The treatment of experimental and control classes was given 6 times. The average value of the group is given after the treatment is $74.04 \pm 10.30$ and the average control group $54.78 \pm 11.96$. Both data are declared to be a normal and homogeneous distribution, subsequent hypothesis testing conducted with $\mathrm{t}$-test that received the result $t_{\text {result }}=6.867 t_{\text {table }}=2.000$ in terms of $5 \%$ significance with degree of freedom $=33+30-2=61$. Based on the calculation of the t-test, it can be withdrawn with the help of a snowball throwing learning model with audio visual aid to the students ' IPA knowledge competence. This research proves that the snowball throwing learning model assisted by audio visual media is well applied in the learning process as an effort to increase students' knowledge of science.
\end{abstract}

\footnotetext{
* Corresponding author. 


\section{PENDAHULUAN}

Sains dan Tekonologi yang berkembang selama ini telah memberikan dampak positif sehingga kehidupan manusia menjadi sejahtera dan mengalami kemajuan yang pesat. Perkembangan sains dan teknologi tidak dapat dipungkiri berjalan seimbang dengan ilmu pengetahuan. Inovasi - inovasi baru yang diciptakan oleh kemajuan IPTEK telah memberikan kemudahan pada setiap kegiatan, serta memberikan cara alternatif dalam melakukan suatu pekerjaan (Tuslina, 2015). Kemajuan Ilmu Pengetahuan dan Teknologi jika dikaitkan dengan dunia edukasi terhubung dengan perkembangan dalam bidang sains, hal ini dikarenakan perkembangan sains yang mengakibatkan perkembangan teknologi. Produk - produk teknologi yang diciptakan oleh para ilmuan inilah yang juga membawa kemajuan dalam mutu pendidikan sains (Wuryastuti, 2008:5). Sains dapat dipelajari dan dikembangkan melalui dunia pendidikan.

Mutu pendidikan Sains di Indonesia jika dibandingkan Negara lain masih tergolong rendah. Pada tahun 2015 pencapaian hasil Trends in International Mathematics and Science Study (TIMSS) melaporkan Indonesia berada pada peringkat 36 dari 39 negara yang memiliki skor terendah. Pencapaian nilai Programme for International Student Assesment (PISA) Indonesia untuk 2015 menempati peringkat 64 dari 72 negara. Meski Indonesia telah naik enam peringkat yang sebelumnya pada tahun 2012 berada pada peringkat 71, Indonesia masih termasuk ke dalam barisan Negara dengan kualitas pendidikan sains yang rendah. Mendapatkan skor 403 menjadikan Indonesia berada pada posisi ke-9 terendah (Novita, 2018). Hal ini membuktikan bahwa kualitas pendidikan IPA di Indonesia masih rendah dan menjadi masalah yang kronis.

Kualitas pendidikan IPA yang rendah ini menyebabkan SDM di Indonesia belum mampu bersaing dengan Negara lainnya dalam era globalisasi saat ini. Pendidikan di Indonesia diharapkan dapat menjawab dan menghadapi tantangan masa depan, dengan membekali generasi muda Indonesia dengan ilmu pengetahuan, soft skill, serta karakter berdasarkan nilai-nilai Pancasila sehingga mampu bertahan dan berkarya di era globalisasi (Dantes, 2014). Tingkat satuan pendidikan di Indoneseia yang dianggap sebagai dasar pendidikan adalah sekolah dasar. Pengertian sekolah dasar dapat dikatakan sebagai kegiatan yang mendasari tiga aspek yakni pengetahuan, sikap, dan keterampilan. Salah satu pokok pelajaran yang wajib untuk diajarkan pada jenjang sekolah dasar yakni IPA.

IPA merupakan ilmu yang mempelajari tentang alam semesta. Meskipun termasuk mata pelajaran pokok, selama ini siswa masih menganggap IPA sebagai pelajaran yang sukar baik siswa dalam jenjang sekolah dasar maupun jenjang sekolah menengah (Susanto, 2016). Observasi dan wawancara yang dilakukan pada siswa dan wali kelas V di SD Gugus RA Kartini menemukan bahwa penguasaan kompetensi pengetahuan IPA siswa belum optimal, nilai KKM belum dicapai sebagian besar siswa. Dalam mengikuti pembelajaran tematik muatan materi IPA, siswa masih banyak yang kurang fokus dan kurang termotivasi dalam mengikuti pembelajaran di kelas sehingga materi yang diajarkan oleh guru belum sepenuhnya mereka pahami, hal ini terlihat ketika guru mengulas kembali pelajaran dengan mengajukan pertanyaan kepada siswa hanya beberapa saja yang mengacungkan tangan lalu menjawab. Hal ini mengakibatkan rendahnya penguasaan kompetensi pengetahuan IPA siswa.

Sehubungan dengan rendahnya penguasaan kompetensi pengetahuan IPA di Indonesia saat ini pemerintah telah melakukan berbagai upaya diantaranya penataan kembali kurkikulum pendidikan, mengadakan penataran bagi guru terkait dengan sistem pembelajaran, menyediakan fasilitas bagi sekolah sebagai penunjang pembelajaran, penyediaan buku - buku sebagai bahan ajar, dan melaksanakan kegiatan Musyawarah Guru Mata Pelajaran (MGMP). Selain upaya diatas, upaya lainnya yang telah dilakukan oleh pemerintah adalah mengadakan program PPG bagi guru. Selain program tersebut, faktor lain yang harus dilakukan untuk membentuk seorang guru yang menguasai kompetensi-kompetensi guru sesuai dengan standar nasional pendidikan adalah perlunya perubahan paradigma dalam belajar mengajar di sekolah. Berkaitan dengan proses belajar mengajar di sekolah, dua hal yang harus diperhatikan adalah model serta media yang digunakan guru dalam menyampaikan materi. Kedua aspek ini sangat berkaitan, pemilihan model pembelajaran tentu mempengaruhi media yang digunakan. Selain hal tersebut, dalam hal memilih model pembelajaran, aspek lain yang harus diperhatikan diantaranya tujuan pembelajaran, lingkungan, fasilitas pendukung, kompetensi pengetahuan yang dikuasai siswa dan karakteristik siswa itu sendiri (Azhar Arsyad, 2009).

Karakter siswa pada usia 6 - 11 tahun yang merupakan kelanjutan dari perkembangan tahap sebelumnya, memiliki sikap yang sangat aktif untuk mempelajari berbagai hal yang ada di lingkungannya (Hartinnah, 2008). Hal ini sejalan dengan Piaget (dalam Susanto, 2016) yang menyatakan bahwa anakanak yang berusia antara 6 atau 7 tahun sampai 11 tahun atau 12 tahun masuk dalam kategori fase operasional konkret. Fase ini menunjukkan tingginya sikap keingintahuan anak-anak untuk mengenali lingkungannya. Usia 11 tahun merupakan puncak dari masa ini dimana anak - anak pada usia ini duduk di bangku kelas 5 SD. Dengan memperhatikan karakteristik siswa, agar tercipta pembelajaran yang efektif 
guru diharuskan untuk menciptakan dan melaksanakan pembelajaran yang menyenangkan, bermakna, dinamis, kreatif, dan logis Maka dari itu perlu digunakannya suatu model pembelajaran yang kreatif, efektif, aktif, komunikatif, dan menciptakan suasana ceria di dalam kelas. Model dapat menjadi alternatif model pembelajaran yang dapat digunakan oleh guru adalah snowball throwing

Model snowball throwing merupakan model pembelajaran yang dirancang seperti permainan. Pelaksanaan model ini yaitu membentuk kelompok-kelompok yang dalam satu kelompok terdapat 4-5 siswa kemudian para siswa menuliskan pertanyaan yang bersangkutan dengan materi, pertanyaan tersebut ditulis pada secarik kertas kemudian dibentuk menyerupai sebuah bola lalu bola kertas dilempar dari siswa satu ke siswa yang lain kemudian siswa diberi kesempatan untuk mengambil bola yang terjatuh di sekitarnya dan menjawab pertanyaan yang tertulis di kertas yang mereka ambil. Kusumawati (2017) menyatakan bahwa keuntungan dari model yang mengajak siswa bermain melempar bola salju ini dapat meningkatkan keaktifan siswa dalam belajar dikarenakan setiap siswa harus berpikir secara individu dan mandiri untuk menuliskan sebuah pertanyaan dan menjawab pertanyaan dari teman temannya, dan mengajarkan siswa dengan segala kemungkinan karena mereka tidak dapat menerka pertanyaan yang dibuat oleh temannya. Suasana belajar di kelas jadi menyenangkan dan bermakna serta dapat motivasi belajar siswa meningkat dengan digunakannya model snowball throwing ini (Akhiriyah, 2011). Pengimplementasian model snowball throwing di kelas dianggap ekfektif, dikarenakan model pembelajaran ini mampu meningkatkan keaktifan siswa dengan melemparkan "bola salju", yang dimaksudkan bola salju adalah kertas berisikan pertanyaan yang dibuat oleh siswa. Melalui pembelajaran dengan model ini juga dapat menggali pemikiran kritis siswa yang dituangkan dalam pertanyaan yang mereka tulis dan saat mereka menjawab pertanyaan yang ditulis temannya, dengan kata lain model snowball throwing memotivasi siswa untuk berpikir dan aktif selama proses pembelajaran. Model pembelajaran semakin efektif apabila didukung oleh media pembelajaran (Oktaviani et al., 2019)

Media pembelajaran merupakan alat bantu pembelajar dalam mengajar serta sarana pembawa pesan dari sumber belajar ke penerima pesan belajar (Falahudin, 2014). Dengan digunakannya media pembelajaran maka materi yang guru sampaikan menjadi lebih mudah untuk dipahami siswa. Satu diantara beragamnya media yang dapat guru gunakan yakni media berupa audio visual yang mengandung gambar dan suara seperti film, video, dan lainnya. Kelebihan media ini diantaranya menampilkan gambar dan suara sekaligus sehingga dapat membangkitkan antusiasme siswa dalam mengikuti pelajaran dan dapat mempermudah penyampaian materi oleh guru (Ahmadi \& Ibda, 2018). Dengan digunakannya model dan media pembelajaran yang tepat maka fokus penilaian dalam kurikulum 2013 siswa dalam mencapai standar kompetensi yang ditentukan yang meliputi 3 jenis kompetensi akan tercapai.

Kompetensi pada kurikulum 2013 meliputi 3 komponen yakni pengetahuan (kognitif), sikap (afektif), dan keterampilan (psikomotor). Salah satu kompetensi yang didapat setelah proses pembelajaran adalah penguasaan kompetensi pengetahuan (kognitif). Kognitivist memandang bahwa aspek kognitif, proses belajar, memori, dan pengetahuan memiliki hubungan yang erat. Kemampuan kognitif merupakan potensi yang digunakan seseorang dalam proses belajar sehingga mampu menyimpan (memori) seoptimal mungkin semua informasi yang diperoleh agar dapat diendapkan dalam bentuk pengetahuan. Jadi dapat ditarik kesimpulan bahwa aspek kognitif dipandang sebagai proses dan kemampuan untuk memperoleh pengetahuan sebagai akibat proses berpikir. Perkembangan kognitif merupakan aspek perkembangan manusia yang berkaitan dengan pemikiran logis yang dimulai dari bayi hingga tumbuh dewasa (Ibda, 2015). Anak-anak yang berusia 6 sampai 12 tahun termasuk dalam fase operasional konkret, pada fase ini anak sudah mampu untuk berpikir rasional dalam menyelesaikan permasalahan yang ada. Aspek kognitif dipandang sebagai proses, jika dikaitkan dengan aktivitas pembelajaran dalam mengkonstruksi suatu pengetahuan. Teori Bloom yang dimodifikasi oleh Anderson dan Krathwohl (dalam Suharsimi, 2018) mengklasifikasikan ranah belajar kognitif terdiri atas enam kategori, antara lain: (C1) mengingat, (C2) memahami, (C3) mengaplikasikan, (C4) menganalisis, (C5) mengevaluasi, (C6) mencipta.

IPA adalah ilmu yang mempelajari tentang segala isi dari alam semesta melalui penginderaan, prosedur, serta penalaran sehingga dapat menghasilkan sebuah kesimpulan (Susanto, 2016). IPA meliputi 3 komponen yaitu produk, proses, dan sikap. Pertama, IPA sebagai produk merupakan kumpulan dari konsep, fakta, teori, hukum, dan prinsip. IPA sebagai proses merupakan tahapan atau prosedur sistematis untuk menggali pengetahuan hingga menghasilkan suatu produk. IPA sebagai sikap merupakan tindakan manusia yang disesuaikan dengan sikap - sikap ilmiah diantaranya: jujur, rasa keingintahuan yang tinggi, teliti, objektif, tekun, dan percaya diri. Pembelajaran IPA bagi siswa kelas V SD adalah sebuah proses belajar dalam rangka mempelajari seluruh benda yang ada di alam semesta dan pengetahuan tentang fenomena atau sejarah alam, dan melalui pembelajaran ini diharapkan siswa terlibat aktif menggali informasi, serta dapat menerapkannya ke dalam keseharian mereka sesuai dengan apa yang dipelajari. Aspek penting dalam pembelajaran IPA di SD adalah harus melibatkan siswa secara aktif dan 
mengembangkan kemampuan berpikirnya. Kegiatan dalam belajar IPA harus dirancang agar siswa diberikan kesempatan untuk bertanya sebanyak mungkin, dengan pertanyaan inilah siswa mampu untuk memberikan gagasan, ide atau pendapatnya terhadap permasalahan yang terjadi di sekitarnya, melatih siswa untuk lebih peka dan peduli kepada lingkungan sekitar Laindjong et al., (2014). Berdasarkan pemaparan diatas maka kompetensi pengetahuan IPA merupakan suatu perubahan perilaku siswa yang mencerminkan kemampuan siswa terhadap penguasaan pembelajaran IPA dari segi pengetahuan setelah mengalami proses belajar.

Snowball throwing jika diterjemahkan ke dalam Bahasa Indonesia berarti lempar bola salju. Bola salju yang dimaksudkan adalah kertas yang berisi satu pertanyaan yang dituliskan oleh siswa sesuai materi yang yelah diajarkan guru kemudian kertas dibentuk bulat menyerupai bola Agustina (2013). Hakim \& Pramukantoro (2013) menerangkan bahwa model pembelajaran snowball throwing adalah sebuah cara menyajikan materi yang dirancang seperti permainan melempar bola. Melalui model ini pemikiran kritis siswa akan dibangun dan mendapat kesempatan untuk menambahkan dan menggali pengetahuan baru sesuai dengan hal-hal yang pernah mereka alami. Shoimin, (2017) memaparkan kelebihan model pembelajaran snowball throwing yakni : (1) Menjadikan siswa aktif dalam pembelajaran, (2) Aktivitas belajar menjadi joyfull atau penuh dengan kegembiraan karena siswa seperti bermain lempar bola salju (3) Kemampuan berpikir kritis siswa dilatih melalui instruksi membuat dan menjawab pertanyaan (4) Mempersiapkan siswa dengan segala situasi karena siswa tidak dapat menerka pertanyaan yang dibuat temannya (5) Melatih kepercayaan diri siswa dalam mengemukakan pendapatnya di depan umum (6) Pembelajaran menjadi efektif dan komunikatif sehingga tercapainya tujuan pembelajaran secara optimal (7) Aspek kognitif, afektif, dan psikomotor siswa dapat tercapai.

Beberapa penelitian mengungkapkan bahwa model snowball throwing efektif digunakan dalam upaya meningkatkan hasil belajar siswa. Sunistini Luh et al., (2013) dalam penelitiannya mengungkapkan bahwa model snowball throwing mampu meningkatkan hasil belajar matematika siswa. Kurnia (2013) dalam penelitiannya mengungkapkan bahwa model pembelajaran kooperatif tipe snowball throwing dapat meningkatkan aktivitas dan hasil belajar siswa pada pembelajaran PKn. Penelitian yang dilaksanakan oleh Kamela (2015) menemukan bahwa hasil belajar IPA siswa kelompok eksperimen yang belajar menggunakan model pembelajaran kooperatif tipe snowball throwing lebih tinggi dibandingkan dengan siswa kelas kontrol yang dibelajarkan menggunakan pembelajaran konvensional.

Model snowball throwing akan lebih bermakna apabila dilengkapi dengan media audio visual sebagai alat bantu guru dalam menyampaikan pembelajaran kepada siswa. Beberapa penelitian menemukan bahwa model snowball throwing efektif digunakan dalam meningkatkan kompetensi pengetahuan IPA siswa. Audio visual dapat dilihat sekaligus didengar oleh siswa karena menyatukan gambar dan suara sehingga pemahaman siswa mengenai materi dapat dipermudah (Sulfemi \& Nurhasanah, 2018). Dilihat dari kemampuan memahami materi tentu saja masing-masing siswa memiliki perbedaan karena ada siswa yang memahami materi hanya dengan mendengar, ada yang memahami hanya dengan melihat dan ada pula siswa yang memahami materi dengan mendengar dan melihat jadi media ini efektif untuk dipergunakan dalam penyampaian materi. Audio visual dapat menyampaikan informasi, memaparkan konsep yang rumit, dan menyajikan materi yang kurang mampu siswa pahami hanya dengan mendengar. Media audio visual menjadikan indra pendengaran dan penglihatan siswa aktif karena mengandung unsur suara dan gambar sehingga pada umumnya media ini dianggap lebih menarik (Sani, 2019). Berdasarkan uraian tersebut maka tujuan penelitian ini adalah mengkaji pengaruh model pembelajaran snowball throwing terhadap kompetensi pengetahuan IPA siswa kelas V SD Negeri Gugus RA Kartini tahun ajaran 2019/2020.

\section{METODE PENELITIAN}

Jenis penelitian ini adalah quasi eksperimen dengan desain nonequivalent control group design Quasi eskperimen memiliki kelas kontrol namun tidak sepenuhnya dapat mengontrol variabel luar yang mempengaruhi hal diluar kegiatan penelitian. Penelitian ini dilaksanakan di SD Negeri Gugus RA Kartini Denpasar Barat. Penelitian dilaksanakan dari bulan November 2019 sampai bulan Maret 2020. Sebagai populasi penelitian ialah seluruh siswa kelas V SD Negeri RA Kartini berjumlah 420 siswa yang tersebar menjadi 12 kelas. Kelas VA SD Negeri 19 Pemecutan dan kelas V SD Negeri 15 terpilih menjadi sampel melalui teknik simple random sampling kemudian pre test diberikan kepada kedua sampel. Nilai hasil pretest digunakan untuk penyetaraan kelas sampel, apabila kedua kelas sudah setara maka diadakan pengundian sekali lagi untuk menentukan kelas yang menjadi eksperimen dan kontrol. Kelas yang terpilih menjadi eksperimen yakni kelas VA SD Negeri 19 Pemecutan dan sebagai kelas kontrol yakni kelas V SD Negeri 15 Pemecutan. Metode pengumpulan data yang digunakan dalam penelitian ini adalah tes. Tes merupakan prosedur sistematik untuk mengungkap performansi maksimal peserta didik dalam 
menguasai kompetensi pengetahuan setelah mengalami proses belajar mengajar. Tes ini digunakan untuk mendapat data kompetensi pengetahuan IPA. Tes diberikan di awal dan akhir kegiatan penelitian sesuai desain penelitian yang telah dirancang. Soal pre test sebanyak 30 butir soal untuk kedua sampel mengacu pada materi kelas V SD Tema 4 Sehat Itu Penting Subtema 1 Peredaran Darahku Sehat. Setelah data pre test terkumpul maka dilakukan uji normalitas dan uji homogenitas sebelum menguji kesetaraan kedua sampel. Setelah kedua sampel setara maka perlakuan diberikan sebanyak 6 kali untuk kelas eksperimen dan kontrol. Apabila perlakuan telah dilaksanakan maka kedua kelas baik eksperimen maupun kontrol diberikan post test untuk mengukur kompetensi pengetahuan IPA siswa setelah diberikan perlakuan yang berbeda.

Instrumen yang digunakan untuk mengukur penguasaan kompetensi pengetahuan IPA siswa adalah tes pilihan ganda biasa. Tes PGB ini memiliki 4 option jawaban (a, b, c atau d) dengan jumlah butir soal sebanyak 30. Sebelum memberikan post test, soal terlebih dahulu diuji validitas, daya pembeda, tingkat kesukaran, dan reliabilitasnya. Dari 40 soal yang telah diujikan, diperoleh 7 soal yang kurang dari $r_{\text {tabel }}(0,30)$ berarti ada 7 soal yang tidak valid, dan terdapat 33 soal yang lebih dari $r_{\text {tabel }}(0,30)$ berarti ada 33 soal yang valid. Setelah soal diuji validitasnya maka dilanjutkan dengan pengujian daya pembeda. Dari 33 soal yang diuji daya pembedanya terdapat 16 soal dengan kategori baik, 14 soal dengan kategori cukup dan 3 soal kategori jelek, maka diputuskan 3 soal tersebut didrop. Kemudian uji dilanjutkan dengan uji tingkat kesukaran yang memperoleh hasil sebanyak 4 soal kategori sukar, 19 soal kategori sedang dan 7 soal kategori mudah. Selanjutnya yakni uji reliabilitas yang memperoleh nilai $r_{11}=0,88$ dan $r_{\text {tabel }}=0,70$ sehingga soal tergolong reliabel.

Setelah data terkumpul maka dilanjutkan dengan analisis data menggunakan statistik deskriptif dan inferensial. Uji hipotesis menggunakan uji-t polled varians, sebelum menguji hipotesis data yang terkumpul diuji normalitas dan homogenitasnya.

\section{ANALISIS DAN PEMBAHASAN}

Gambaran kompetensi pengetahuan IPA kelas VA SD Negeri 19 Pemecutan dan kelas V SD Negeri 15 Pemecutan sebelum diberikan perlakuan disajikan pada tabel 1.

Tabel 1. Distribusi Kompetensi Pengetahuan IPA Pre Test

\begin{tabular}{llcc}
\hline Kategori & Nilai Huruf & $\begin{array}{l}\text { Kelas VA SD Negeri 19 } \\
\text { Pemecutan }\end{array}$ & $\begin{array}{c}\text { Kelas V SD Negeri 15 } \\
\text { Pemecutan }\end{array}$ \\
\hline Sangat Baik & A $(85-100)$ & - & - \\
Baik & B $(70-84)$ & 1 & - \\
Cukup & C $(55-69)$ & 6 & 11 \\
Kurang & D $(40-54)$ & 17 & 19 \\
Sangat Kurang & E $(0-39)$ & 10 & 3 \\
\hline
\end{tabular}

Berdasarkan tabel 1 diatas dapat dilihat bahwa pada kelas VA SD Negeri 19 Pemecutan hanya 1 siswa yang dikategorikan baik, 6 siswa kategori cukup, 17 siswa kategori kurang, dan sebanyak 10 siswa kategori sangat kurang. Pada kelas V SD Negeri 15 Pemecutan sebanyak 11 siswa dalam kategori cukup, 19 siswa kategori kurang, dan 3 siswa kategori sangat kurang. Rata - rata nilai kelas VA SD Negeri 19 Pemecutan yakni 45,39 dan kelas V SD Negeri 15 Pemecutan yakni 49,29. Penemuan pada penelitian ini jauh lebih rendah dibandingkan dengan penelitian lain. Penelitian Putrayasa, Syahruddin, \& Margunayasa (2014) terhadap siswa kelas V SD di Desa Bontihing, Kecamatan Kubutambahan memperoleh rata-rata nilai siswa sebelum diberikan perlakuan yakni 70,38. Penelitian yang dilaksanakan oleh Santiasih (2013) terhadap siswa kelas V SD No 1 Kerobokan memperoleh rata-rata nilai yakni 74,33. Sebelum dilakukan uji kesetaraan, terlebih dahulu dilakukan uji prasyarat yang meliputi uji normalitas data dan uji homogenitas varians. Dari hasil analisis prasyarat yaitu uji normalitas dan uji homogenitas diperoleh data dari kedua sampel berdistribusi normal dan homogen, kemudian dilanjutkan dengan uji kesetaraan dengan uji-t yang memperoleh $t_{\text {hitung }}=-1,539$ dan $t_{\text {tabel }}=2,000$, karena $t_{\text {hitung }}<t_{\text {tabel }}$ maka kompetensi pengetahuan IPA kedua sampel dinyatakan setara Gambaran kompetensi pengetahuan kelas eksperimen dan kontrol sesudah diberikan perlakuan disajikan pada tabel .

Tabel 2. Distribusi Kompetensi Pengetahuan IPA Post Test

$\begin{array}{llllllll}\text { Kategori } & \text { Nilai Huruf } & \text { Kelas VA SD Negeri } 19 & \text { Kelas } & \text { V } & \text { SD } & \text { Negeri } & 15\end{array}$




\begin{tabular}{cccc}
\hline & & Pemecutan & Pemecutan \\
\hline Sangat Baik & A $(85-100)$ & 6 & - \\
Baik & B $(70-84)$ & 16 & 4 \\
Cukup & C $(55-69)$ & 10 & 11 \\
Kurang & D $(40-54)$ & 1 & 13 \\
Sangat Kurang & E $(0-39)$ & - & 2 \\
\hline
\end{tabular}

Berdasarkan tabel 2 diatas dapat dilihat bahwa pada kelas eksperimen 6 siswa dalam kategori sangat baik, 16 siswa kategori baik, 10 siswa kategori cukup, dan 1 siswa kategori sangat kurang. Pada kelas kontrol sebanyak 4 siswa kategori baik, 11 orang siswa kategori cukup, 13 siswa kategori kurang, dan 2 siswa kategori sangat kurang. Rata - rata nilai kelas eksperimen lebih dari kelas kontrol yakni 74,04 $>54,68$. Penemuan pada penelitian ini sejalan dengan hasil pada penelitian lain bahwa rata - rata nilai pada siswa kelas eksperimen lebih dari siswa kelas kontrol antara lain: 76,09 > 67,88 (Susanti et al., 2014); 83,50 > 71,20 (Dewi, 2013); 83,23 > 71,47 (Kusumawati, 2017). Hal ini terjadi karena pada proses pembelajaran IPA kelompok eksperimen menggunakan model pembelajaran snowball throwing berbantuan media audio visual. Sebelum dilakukan pengujian hipotesis, terlebih dahulu dilakukan uji prasyarat yang meliputi uji normalitas data dan uji homogenitas varians. Dari hasil analisis prasyarat yaitu uji normalitas dan uji homogenitas diperoleh data dari kelas eksperimen dan kelas kontrol berdistribusi normal dan homogen, kemudian dilanjutkan dengan uji Hipotesis. Hipotesis yang diuji adalah Hipotesis Nol ( $\mathrm{HO}$ ) yang menyatakan tidak terdapat perbedaan yang signifikan kompetensi pengetahuan IPA antara siswa yang belajar melalui model pembelajaran snowball throwing berbantuan media audio visual dengan siswa yang belajar melalui pembelajaran konvensional pada siswa kelas V SD Negeri Gugus RA Kartini Tahun Pelajaran 2019/2020 sedangkan hipotesis alternatifnya (Ha) adalah terdapat perbedaan yang signifikan kompetensi pengetahuan IPA antara siswa yang belajar melalui model pembelajaran snowball throwing berbantuan media audio visual dengan siswa yang belajar melalui pembelajaran konvensional pada siswa kelas V SD Negeri Gugus RA Kartini Tahun Pelajaran 2019/2020.

Pengujian hipotesis melalui uji $\mathrm{t}$, dari hasil perhitungan $\mathrm{dk}$ (derajat kebebasan) diperoleh nilai dengan taraf signifikansi $5 \%(\alpha=0,05)$ dan $d k=30+33-2=61$ adalah 2,000 . Jika $t_{\text {hitung }}<t_{\text {tabel }}$, maka HO diterima dan Ha ditolak, sebaliknya jika $t_{\text {hitung }} \geq t_{\text {tabel }}$, maka HO ditolak dan Ha diterima. Hasil penghitungan uji hipotesis dapat dilihat pada Tabel 3.

Tabel 3. Rekapitulasi Hasil Uji-t

\begin{tabular}{lccc}
\hline \multicolumn{1}{c}{ Sampel } & $\mathrm{t}_{\text {hitung }}$ & $\mathrm{t}_{\text {tabel }}$ & Keterangan \\
\hline $\begin{array}{l}\text { Kelas Eksperimen } \\
\text { Kelas Kontrol }\end{array}$ & 6,867 & 2,000 & Ho ditolak \\
\hline
\end{tabular}

Pemerolehan hasil uji-t didapat $\mathrm{t}_{\text {hitung }}=6,867$ dan dalam taraf signifikansi 5\% dengan $\mathrm{dk}=33+30-$ $2=61$ diperoleh $t_{\text {tabel }}=2,000$. Dengan membandingkan hasil $t_{\text {hitung }}$ dan $t_{\text {tabel }}$ dapat disimpulkan bahwa $t_{\text {hitung }}$ $>t_{\text {tabel }}(6,867>2,000)$. Hasil penelitian ini sejalan dengan penelitian yang dilakukan oleh Naniek Kusumawati $\left(\mathrm{t}_{\text {hit }}=15,18>\mathrm{t}_{\text {tabel }}=1,684\right)$, Made Puspa Dewi $\left(\mathrm{t}_{\text {hit }}=2,562>\mathrm{t}_{\text {tabel }}=2,000\right)$, dan Handayani et al., ( $\left.\mathrm{t}_{\text {hitung }}=4,160>\mathrm{t}_{\text {tabel }}=1,677\right)$.

Hasil penelitian ini menunjukkan bahwa terdapat perbedaan kompetensi pengetahuan IPA siswa antara kelompok siswa yang menggunakan model pembelajaran snowball throwing berbantuan media audio visual dengan kelompok siswa yang menggunakan model pembelajaran konvensional. Perbedaan tersebut terjadi karena pada pembelajaran konvensional proses pembelajaran lebih cenderung berpusat pada guru sebagai penentu arah pembelajaran. Dalam pembelajaran konvensional, siswa cenderung pasif dan kurang dalam hal kerjasama kelompok. Hal tersebut membuat hasil belajar yang diperoleh kelas kontrol belum optimal. Selain itu, pembelajaran konvensional yang menekankan pada penyelesaian soal serta kurang adanya partisipasi aktif siswa dalam menjalankan kerja kelompok juga membuat hasil belajar yang diperoleh lebih kecil dibandingkan dengan kelas eksperimen. Dalam pembelajaran konvensional yang dilakukan, siswa juga tidak diberikan pembagian tugas yang jelas dalam berkelompok sehingga banyak siswa cenderung hanya sebagai pelaku belajar yang pasif (Santiasih, 2014). Sedangkan pada kelas eksperimen yang dibelajarkan melalui model snowball throwing berbantuan media audio visual, partisipasi siswa dalam proses pembelajaran menjadi aktif. Bayor ( dalam Hardini \& Akmal, 2017) menyatakan bahwa model snowball throwing merupakan model yang dalam pelaksanaanya banyak melibatkan siswa. Menurut Farhan (dalam Sandi et al., 2014) snowball throwing merupakan salah satu model yang didalamnya terdapat kerjasama, terciptanya suasana pembelajaran yang ceria, aktif, dan 
komukatif. Penggunaan model ini ekfektif, karena mampu meningkatkan keaktifan siswa dengan melempar bola kertas berisikan pertanyaan

Temuan penelitian ini didukung oleh beberapa hasil penelitian yang dilakukan oleh peneliti terdahulu. Susanti (2014) menemukan bahwa terdapat perbedaan rata-rata penguasaan kompetensi IPA siswa yang dibelajarkan melalui model snowball throwing lebih baik dibandingkan dengan siswa yang tidak dibelajarkan melalui model snowball throwing. Dewi (2013) menyatakan bahwa terdapat perbedaan antara nilai rata-rata hasil belajar kelompok eksperimen dengan nilai rata-rata kelompok kontrol (83,50 > 71,20). Penelitian yang dilaksanakan oleh Kusumawati (2017) memaparkan bahwa hasil belajar siswa kelas eksperimen yang menerapkan model pembelajaran snowball throwing memiliki rata-rata 83,23 sedangkan pada siswa kelas kontrol memperoleh rata-rata 71,47. Hal ini membuktikan bahwa hasil belajar siswa kelas eksperimen lebih baik dibandingkan dengan kelas kontrol. Melalui penggunaan model snowball throwing siswa diberikan kesempatan untuk mengeksplor pengetahuan mereka melalui diskusi kelompok, membuat dan menjawab pertanyaan, serta merangkum proses pembelajaran sehingga kompetensi pengetahuan IPA siswa akan meningkat. Wahyuningsih (dalam Wangsa et al., 2019) menyatakan bahwa model snowball throwing mampu mendorong motivasi siswa dalam belajar yang ditunjukkan dari meningkatnya pemberian pendapat maupun sanggahan dalam kegiatan pembelajaran. Ayu et al., (2013) memaparkan bahwa pemahaman konsep siswa yang dibelajarkan melalui model snowball throwing lebih baik dibandingkan siswa yang tidak dibelajarkan melalui model snowball throwing.

Model pembelajaran ini juga menggali kemampuan berpikir kritis siswa yang dituangkan dalam pertanyaan yang mereka tulis dan saat mereka memberi jawaban atas pertanyaan yang mereka dapatkan. Dalam artian model pembelajaran snowball throwing memotivasi siswa untuk berpikir dan aktif selama proses pembelajaran. Disamping hal tersebut Irma \& Susilo (2013) menyatakan bahwa melalui model ini potensi kepemimpinan dan sikap tanggung jawab siswa akan dilatih. Setiap siswa yang menjadi ketua kelompok bertanggung jawab memaparkan kembali materi yang disampaikan oleh guru kepada anggota kelompoknya (Pahyanti, 2013). Mereka bertugas untuk mengatur kondisi kelompoknya agar tetap kondusif dan tidak gaduh. Tanggung jawab setiap siswa terlihat dalam membuat soal dan memberikan jawaban terhadap soal temannya. Pengetahuan yang mereka dapatkan di dalam kelas diharapkan dapat diimplementasikan ke dalam kehidupan sehari-hari baik dirumah maupun di lingkungan bermain (Primayana, 2019). Hal ini akan menjadikan siswa lebih bersemangat dalam menghadapi suatu persoalan, lebih bijak dalam menganalisa suatu pertanyaan, lebih bertanggung jawab dalam menghadapi suatu permasalahan tidak mengandalkan orang lain untuk menyelesaikan permasalahan yang dihadapinya, dan menghormati pendapat orang lain.

Secara operasional, kedua model pembelajaran tersebut diterapkan pada saat mengajarkan materi yang sama namun dengan cara penyampaian yang berbeda sehingga memberikan hasil yang berbeda pula. Melalui perbedaan hasil tersebut, maka penggunaan model pembelajaran snowball throwing berbantuan media audio visual dalam proses pembelajaran dapat dikatakan memberikan pengaruh yang lebih baik dibandingkan dengan penerapan pembelajaran konvensional

\section{KESIMPULAN}

Berdasarkan hasil pengujian hipotesis dan pembahasan maka simpulan dari penelitian ini terdapat pengaruh signifikan model snowball throwing berbantuan media audio visual terhadap kompetensi pengetahuan IPA siswa kelas V SD Negeri Gugus RA Kartini tahun ajaran 2019/2020. Adapun saran yang dapat disampaikan yaitu kepada guru hendaknya dapat menambah wawasannya mengenai inovasi pembelajaran sehingga mampu menerapkan pembelajaran di kelas secara lebih inovatif dan bervariasi agar dapat memberikan dampak positif dalam meningkatkan kompetensi pengetahuan siswa. Kepada Sekolah, hendaknya dapat berkontribusi penuh dalam meningkatkan kualitas serta mengoptimalkan proses pembelajaran, sehingga berdampak positif pada kompetensi pengetahuan siswa khususnya di Sekolah Dasar. Kepada peneliti lain, agar dapat mengembangkan berbagai model pembelajaran lain pada subjek penelitian yang berbeda sehingga proses pembelajaran IPA dapat berlangsung optimal dan memberikan dampak positif bagi kompetensi pengetahuan IPA siswa. 


\section{DAFTAR PUSTAKA}

Agustina, E. T. (2013). Implementasi Model Pembelajaran Snowball Throwing Untuk Meningkatkan Hasil Belajar Siswa Dalam Membuat Produk Kria Kayu. IX(1), 17-28. Https://Ejournal.Upi.Edu/Index.Php/Invotec/Article/Viewfile/4881/3421

Ahmadi, F., \& Ibda, H. (2018). Media Literasi Sekolah (Teori Dan Praktik) (Hal. Xii + 492 Hlm). CV Pilar Nusantara.

Akhiriyah, D. Y. (2011). Penerapan Model Pembelajaran Snowball Throwing Untuk Meningkatkan Kualitas Pembelajaran IPS Pada Siswa Kelas V SDN Kalibanteng Kidul 01 Kota Semarang, 1, 206-219. Https://Journal.Unnes.Ac.Id/Nju/Index.Php/Kreatif/Article/View/1682

Ayu, P. D., Parmiti, D. P., \& Widiana, I. W. (2013). Pengaruh Model Pembelajaran Snowball Throwing Dan Motivasi Belajar Terhadap Pemahaman Konsep Ipa Siswa. MIMBAR PGSD Undiksha, 2(1). Https://Doi.Org/10.23887/Jjpgsd.V2i1.3603

Dantes, N. (2014). Landasan Pendidikan Tinjauan Dari Dimensi Makropedagogis. Graha Ilmu.

Dewi, P. (2013). Pengaruh Model Pembelajaran Snowball Throwing Terhadap Hasil Belajar Ipa Siswa Kelas $V \quad S d \quad D i \quad G u g u s$ Sri Kandi Kecamatan Denpasar Timur. 10. Https://Ejournal.Undiksha.Ac.Id/Index.Php/JJPGSD/Article/View/924

Falahudin, I. (2014). Pemanfaatan Media Dalam Pembelajaran. 104-117.

Hakim, A. H. R., \& Pramukantoro, J. A. (2013). Pengaruh Perpaduan Metode Pembelajaran Snowball Throwing Dengan Talking Stick Terhadap Hasil Belajar Siswa Pada Standar Kompetensi Menerapkan Dasar-Dasar Elektronika. 01(2), 11-20.

Handayani, T., Widyaningsih, S. W., Yusuf, I., Papua, M., \& Indonesia, B. (2017). Penerapan Model Pembelajaran Kooperatif Tipe Snowball Throwing Terhadap Hasil Belajar Peserta Didik. Curricula: $\begin{array}{lllll}\text { Journal Of Teaching And } & \text { 40arning, }\end{array}$ Http://Ejournal.Lldikti10.Id/Index.Php/Curricula/Article/Viewfile/1543/666

Hardini, A. T. A., \& Akmal, A. (2017). Penerapan Metode Snowball Throwing Berbantuan Media Konkret Untuk Meningkatkan Keaktifan Dan Hasil Belajar IPA Siswa Kelas IV Sekolah Dasar. Jurnal Pendidikan Dasar Perkhasa, 3(1), 223-245. Https://Media.Neliti.Com/Media/Publications/271606Penerapan-Metode-Snowball-Throwing-Berba-63d597b9.Pdf

Hartinnah, S. (2008). Perkembangan Peserta Didik (A. Saridewi (Ed.); Pertama). PT Refika Aditama.

Ibda, F. (2015). Perkembangan Kognitif: Teori Jean Piaget. 3. Https://Www.Jurnal.ArRaniry.Ac.Id/Index.Php/Intel/Article/View/197

Irma, A., \& Susilo, S. (2013). Peningkatan Kualitas Pembelajaran Ips Menggunakan Snowball Throwing Media Audio Visual Kelas Iv. Joyful Learning Journal, 2(3), 70-77. Https://Journal.Unnes.Ac.Id/Sju/Index.Php/Jlj/Article/View/2097

Kamela, T. (2015). Pengaruh Model Snowball Throwing Berbantuan Multimedia Interaktif Terhadap Hasil Belajar. E-Journal Edutech Universitas Pendidikan Ganesa Vol. 3 No. 1 Universitas Pendidikan Ganesha, 3(1). Https://Ejournal.Undiksha.Ac.Id/Index.Php/JEU/Article/View/5596

Kurnia, I. (2013). Penerapan Model Pembelajaran Kooperatif Tipe Snowball Throwing Untuk Meningkatkan Hasil Belajar Pkn. Journal of Elementary Education, 2(2), 25-29. Http://Journal.Unnes.Ac.Id/Sju/Index.Php/Jee

Kusumawati, N. (2017). Pengaruh Model Pembelajaran Kooperatif Dengan Snowball Throwing Terhadap Hasil Belajar IPA Pada Siswa Kelas IV SDN Bondrang Kecamatan Sawoo Kabupaten Ponorogo. Ibriez : 
Jurnal Kependidikan Dasar Islam Berbasis Sains, 2(1), 1-12.

Https://Doi.Org/10.21154/Ibriez.V2i1.19

Laindjong, S. N., Alibasyah, L. M. P., \& Paudi, I. (2014). Meningkatkan Hasil Belajar Siswa Pada Pembelajaran Dengan Menggunakan Media Gambar Di Kelas V SDN 05 Biau. Jurnal Kreatif Tadulako Online, 5(3), 51-62. Https://Media.Neliti.Com/Media/Publications/111807-ID-Meningkatkan-HasilBelajar-Siswa-Pada-Pe.Pdf

Novita, F. (2018). Pisa Dan Literasi Indonesia. Kompasiana. Https://Www.Kompasiana.Com/Frncscnvt/5c1542ec677ffb3b533d6105/Pisa-Dan-LiterasiIndonesia?Page=All

Oktaviani, Suwatra, I. W., \& Murda, N. (2019). Pengaruh Model Pembelajaran Snowball Throwing Berbantuan Media Audiovisual Terhadap Hasil Belajar Bahasa Indonesia. Jurnal Ilmiah Sekolah Dasar, 3(1), 89-97. Https://Ejournal.Undiksha.Ac.Id/Index.Php/JISD/Article/View/17662

Pahyanti, N. (2013). Peningkatan Tanggung Jawab Siswa Melalui Model Snowball Throwing Pada Siswa YPP Purworejo Kelas X TM C. EKUIVALEN - Pendidikan Matematika, 5(1), 26-33. Http://202.91.10.52/Index.Php/Ekuivalen/Article/View/699

Primayana, K. H. (2019). Pengaruh Model Pembelajaran Kontekstual Berbasis Lingkungan Terhadap Hasil Belajar Ipa Ditinjau Dari Minat Outdoor Pada Siswa Kelas Iv. Jurnal Pendidikan Dan Pembelajaan IPA Indonesia, 9(2), 72-79. $\quad$ Http://119.252.161.254/E-Journal/Index.Php/Jurnal Ipa/Arti cle/View/2905

Putrayasa, I. M., Syahruddin, H., \& Margunayasa, I. G. (2014). Pengaruh Model Pembelajaran Discovery Learning Dan Minat Belajar Terhadap Hasil Belajar Ipa Siswa. Jurnal Mimbar PGSD Universitas Pendidikan Ganesha, 2. Https://Ejournal.Undiksha.Ac.Id/Index.Php/JJPGSD/Article/View/3087

Sandi, I. K., Suwatra, I. W., \& Widiana, I. W. (2014). Pengaruh Model Pembelajaran Snowball Throwing Terhadap Hasil Belajar Ipa Dengan Kovariabel Kemampuan Berpikir Kreatif Siswa Kelas IV SD. 2(1), 1-10. Https://Ejournal.Undiksha.Ac.Id/Index.Php/JPGSD/Article/View/3203

Sani, R. A. (2019). Strategi Belajar Mengajar (Pertama). PT Raja Grafindo Persada

Santiasih, N. L. (2013). Pengaruh Model Pembelajaran Discovery Learning Dan Minat Belajar Terhadap Hasil Belajar Ipa Siswa. Jurnal Mimbar PGSD Universitas Pendidikan Ganesha, 3.

Santiasih, N. L. (2014). Pengaruh Model Pembelajaran Inkuiri Terbimbing Terhadap Sikap Ilmiah Dan Hasil Belajar IPA Siswa Kelas V SD No. 1 Kerobokan Kecamatan Kuta Utara Kabupaten Badung Tahun Pelajaran 2013/2014. E-Journal Program Pascasarjana Universitas Pendidikan Ganesha, 3(1), 1-11. Https://Media.Neliti.Com/Media/Publications/122294-ID-Pengaruh-Model-PembelajaranInkuiri-Terb.Pdf

Shoimin, A. (2017). 68 Model Pembelajaran Inovatif Dalam Kurikulum 2013 (KR Rose (Ed.); Pertama). ArRuzz Media

Sri Wuryastuti. (2008). Inovasi Pembelajaran IPA Di Sekolah Dasar. Jurnal Pendidikan Dasar, 9(April), 2. Http://103.23.244.11/Direktori/JURNAL/PENDIDIKAN_DASAR/Nomor_9April_2008/Inovasi_Pembelajaran_IPA_Di_Sekolah_Dasar.Pdf

Sulfemi, Bagja, W., \& Nurhasanah. (2019). Pengaruh Model Pembelajaran Snowball Throwing Berbasis Penilaian Kinerja Terhadap Hasil Belajar IPA. International Journal Of Elementary Education., 1(1), 47. Https://Doi.Org/10.23887/Jp2.V1i1.19334

Sulfemi, W. B., \& Nurhasanah. (2018). Pengggunaan Metode Demontrasi Dan Media Audio Visual Dalam Meningkatkan Hasil Belajar Peserta Didik Mata Pelajaran IPS. Jurnal Pendas Mahakam, 3(2), 151158.

Sunistini Luh, Arini, N. W., \& Margunayasa, I. G. (2013). Penerapan Model Snowball Throwing Berbantuan Media Sederhana Untuk Meningkatkan Hasil Belajar Matematika Siswa Di SD No 1 Petandakan. MIMBAR PGSD Undiksha, 1(1). 
Susanti, K. A., Suadnyana, I. N., \& Zulaikha, S. (2014). Pengaruh Model Snowball Throwing Berbantuan Media Konkret Terhadap Hasil Belajar IPA Kelas V SD Gugus Gusti Ngurah Rai Denpasar. E-Journal Mimbar PGSD Universitas Ganesha, 2(1), 1-10.

Susanto, A. (2016). Teori Belajar \& Pembelajaran Di Sekolah Dasar (Pertama). Kencana.

Tuslina, T. (2015). Peranan Ilmu Pengetahuan Alam Dan Teknologi Dalam Memenuhi Kebutuhan Kehidupan Manusia. 